\title{
SOIL PROPERTIES AND TREE COMPOSITION IN A 27-YEAR OLD Acacia mangium Willd. PLANTATION ON ABANDONED MINING AREA AT PHANGNGA FORESTRY RESEARCH STATION**
}

\author{
JETSADA WONGPROM ${ }^{1 *}$, ROONGREANG POOLSIRI ${ }^{2}$, SAPIT DILOKSUMPUN ${ }^{2}$ \\ AND CHATCHAI NGERNSAENGSARUAY ${ }^{3}$ \\ ${ }^{1}$ Faculty of Forestry, Kasetsart University, Bangkok. 10900, Thailand \\ ${ }^{2}$ Department of Silviclture, Faculty of Forestry, Kasetsart University, Bangkok 10900, Thailand \\ ${ }^{3}$ Department of Botany, Faculty of Science, Kasetsart University, Bangkok, 10900, Thailand \\ *Corresponding author, e-mail: fforjdw@ku.ac.th
}

Received 19 December 2018 / Accepted 04 April 2019

\begin{abstract}
In order to validate the important role of Acacia mangium plantation in mining rehabilitation, a study was conducted on the soil properties and tree composition in a 27-year-old $A$. mangium plantation growing on sandy (S27) and clay (C27) soil types, as well as a mixed plantation (MP) growing on clay soil type. The results were compared with those grown on an abandoned mining area (AB), a secondary forest (SF) and a primary forest (PF), at the Phangnga Forestry Research Station, Thailand. Three 40 x $40 \mathrm{~m}$ permanent plots were established and soil samples were randomly collected from depths of 0-10, 10-20, 20-30, and 30-50 cm, in each of the S27, $\mathrm{C} 27, \mathrm{MP}, \mathrm{AB}, \mathrm{SF}$, and PF. The bulk density values in the S27, C27, and MP were lower than that in AB and was similar to those in SF and PF, particularly, the top soil. Total nitrogen, available phosphorus, organic matter, exchangeable potassium, and magnesium contents in the S27, C27, and MP were higher than that in $\mathrm{AB}$, but were lower than those in SF and PF, indicating that the soil development in the S27, C27, and MP was slower than in the SF and PF. This lower bulk density values and higher soil nutrient contents were positively contributed by the $A$. mangium plantation. The Shannon-Wiener index obtained for S27 (1.43), C27 (2.51), and MP (2.77) were lower than that for the SF (3.86). The similarity indices of the tree species found in S27, C27, $\mathrm{MP}$, and PF were low, ranging from 5.83 - 8.00, indicating that the development of the forest community was slow compared to SF (31.03). Enrichment planting with poorly dispersed shade tolerant trees has increased the diversity and improved the forest structure in the mined out areas and other similarly degraded lands.
\end{abstract}

Keywords: Acacia mangium, mining area, soil properties, tree composition

\section{INTRODUCTION}

Ever since mining has been widely operational all over Thailand, the local environment and ecosystem conditions have been severely impacted by the mining activities (Macdonald et al. 2015). Vegetations were destroyed and soil properties were changed from

${ }^{*}$ Corresponding author, e-mail: fforjdw@ku.ac.th

**This paper was presented at the $3^{\text {rd }}$ International Conference on Tropical Biology 2018, 20-21 September 2018, Bogor, West Java, Indonesia the originally rich to currently poor soil. Soil textures have become unsuitable for planting (Oktavia et al. 2015). In some areas, the soil has turned extremely acidic and the soil moisture went very low during the dry season (Tripathi et al. 2016). As a result, soil improvement and forest restoration in mining areas has taken a long time. Invariably, changes in such important factors as soil properties like soil texture, organic matter, $\mathrm{pH}$, nitrogen, phosphorus and potassium have negatively affected the development of a forest community in 
previously mined areas (Zhao et al. 2013; Lei et al. 2015). Oftentimes, nitrogen limits the growth and reestablishment of forest seedlings. As such, natural regeneration using native trees was applied to accelerate plantation establishment. However, restoration of several mined out areas is costly and is usually a long term process (Oktavia et al. 2015).

The popularly known nitrogen fixing tree, Acacia mangium is a multipurpose fast-growing tree which plays an important role in restoring the soil quality of degraded lands. This species has been widely introduced in Southeast Asia (Nambiar \& Harwood 2014). Its survival, growth rate and the aboveground biomass it produces are relatively high compared to other fast growing and native tree species found in abandoned mining areas (Martpalakorn 1990). A. mangium plantation has been established in degraded lands for wood production, forest restoration, as well as soil improvement (Wang et al. 2010). Degraded land restoration using plantation is one approach for catalyzing the natural succession process and increasing the tree species diversity (Tripathi et al. 2016). Since native tree species have been introduced into plantations, resulting in an increased tree species richness and increased forest structure complexity, the restoration of previously mined areas using nitrogen fixing trees has been focused on soil improvement (Bohre \& Chaubey 2014). Generally, after plantation establishment, the soil physical and chemical properties will improve (Zhao et al. 2013; Bohre \& Chaubey 2014), simultaneously with the ecosystem services such as litter supply, nutrient cycling, and biodiversity (Parrotta 1999; Celentano 2011).

The objectives of this study were, firstly; to evaluate the soil properties, tree composition, and diversity of a 27-year-old $A$. mangium plantation located in Phangnga Forestry Research Station, Thailand and compare these with an abandoned mining area $(\mathrm{AB})$, secondary forest (SF) and primary forest (PF) and secondly, to recommend trees, like $A$. mangium, that are suitable for this site restoration programs and for other mined out areas.

\section{MATERIALS AND METHODS}

\section{Study Area}

The experiment was conducted on an abandoned tin mine at Phangnga Forestry Research Station, Takuapa District, Phangnga Province, Thailand. The area also includes a 27year-old $A$. mangium plantation grown on sandy (S27) and, clay (C27) soil types, as well as mixed plantation (MP) of Eucalyptus camaldulensis, A. mangium, and Diptercapus alatus grown on a clay soil type. Phangnga Forestry Research Station is approximately $3 \mathrm{~km}$ away from a primary forest $(\mathrm{PF})$ and is surrounded with rubber and oil palm plantations. The area receives a mean annual rainfall of $3,668.80 \mathrm{~mm}$, with rainy season occurring from April to November and dry season from December to March. Its relative humidity is around $83 \%$ and its mean annual temperature is at $27.1{ }^{\circ} \mathrm{C}$ (Wongprom et al. 2013). In addition, secondary forest $(\mathrm{SF})$, primary forest $(\mathrm{PF})$, and abandoned mining area $(\mathrm{AB})$ were established as reference sites. The SF plot is approximately a 30 -year-old protected forest, a tropical rainforest that was disturbed in the past by shifting cultivation.

\section{Soil Properties}

Soil samples were collected from the S27, C27, MP, AB, SF and PF sites at four soil depth series, $0-10,10-20,20-30$ and $30-50 \mathrm{~cm}$. Three soil pits were randomly established, while soil samples were collected from each plot using a split tube sampler for the soil physical and chemical analyses. For the chemical properties, the samples within each plot were mixed thoroughly to form a soil composite. Soil bulk density was analyzed by the core method, while the soil texture was analyzed by the hydrometer method. Soil $\mathrm{pH}$ was examined by a $\mathrm{pH}$ meter with 1:1 soil: water ratio. Total nitrogen $(\mathrm{N})$ was measured using the Dumas method (Jackson 1965) by CHNS analyzer. Organic matter content (OM) was analyzed by the Walkley and Black rapid titration method. Available phosphorus (P) was extracted using the Bray II method and was analyzed using a spectrometer. The exchangeable potassium (K), calcium (Ca) 
and magnesium $(\mathrm{Mg})$ were extracted with ammonium acetate $\left(\mathrm{NH}_{4} \mathrm{OAc}\right) 1 \mathrm{~N} \mathrm{pH} 7.0$ and analyzed by an atomic absorption spectrometer (Estefan et al. 2013).

\section{Tree Composition}

Three permanent plots of $40 \times 40 \mathrm{~m}$ were established in each of the S27, C27, MP, SF, and PF sites. Each sample plot was divided into sixteen subplots of size $10 \times 10 \mathrm{~m}$ plot. At the permanent plots, all tree species with diameter at breast height $(\mathrm{DBH}) \geq 4.5 \mathrm{~cm}$ were identified and recorded. The DBH and total height of a tree was measured using a diameter tape and Haga altimeter, respectively. Plant specimens were collected and identified, and the unidentified species were compared with the herbarium specimens deposited at the Forest Herbarium, Natural Parks, Wildlife and Plant Conservation Department.

\section{Data Analyses}

Soil physical and chemical properties, including bulk density, porosity, soil $\mathrm{pH}$, total $\mathrm{N}$, available $\mathrm{P}, \mathrm{OM}$, exchangeable $\mathrm{K}, \mathrm{Ca}$, and $\mathrm{Mg}$ were analyzed using a one-way analysis of variance (ANOVA) and the means were compared using Tukey's test at 5\% probability level. The importance value index (IVI), tree density, and basal area were also calculated. The IVI value was obtained as a relative density (RD), relative frequency (RF), and relative dominance (RDo) of a given tree species. The tree species diversity for each site was calculated using the Shannon-Wiener index (Shannon \& Weaver 1949) using the formula:

$$
\mathrm{H}^{\prime}=-\sum_{\mathrm{n}=1}^{\mathrm{n}}\left(\mathrm{pi}{ }^{*} \ln \mathrm{pi}\right)
$$

where, $\mathrm{H}^{\prime}$ is the Shannon-Wiener index, Pi is the proportion of each species in the sample, $\ln \mathrm{Pi}$ is the natural logarithm of this proportion.

Species evenness (E) was calculated as follows (Pielou 1966):

$$
\mathrm{E}=\mathrm{H}^{\prime} / \mathrm{In} \mathrm{S}
$$

where, $H^{\prime}$ is the Shannon-Wiener index and $S$ is total number of species in the sample.

The similarity of plant composition was calculated using the Sørensen similarity index (Sørensen 1948) by the formula:

$\mathrm{S}=2 \mathrm{c} /(\mathrm{a}+\mathrm{b}) \times 100$

where, $\mathrm{S}$ is the Sørensen similarity index, $\mathrm{a}$ is the number of species found in site $A, b$ is the number of species in site $\mathrm{B}$, and $\mathrm{c}$ is the number of species shared by the two sites. ShannonWiener index and the Sørensen similarity index are the most widely used tools to evaluate plant community (Barrantes \& Sandoval 2009; Martínez-Ruiz \& Fernández-Santos 2005; Zhang et al. 2014).

\section{RESULTS AND DISCUSSION}

\section{Soil Physical Properties}

At the top soil $(0-10 \mathrm{~cm})$, the soil bulk density and soil particles were significantly different among the sites but not for porosity (Table 1). However, at soil depths of $10-20$, $20-30$ and $30-50 \mathrm{~cm}$ the bulk density, soil particles, and porosity of the subsoil significantly differed among the different sites. The bulk density was the highest $\left(1.31 \mathrm{~g} / \mathrm{m}^{3}\right)$ in $\mathrm{AB}$, while bulk densities of S27, C27 and MP were similar to SF and PF. The bulk density can be relatively lower in mining areas having a forest plantation (Bohre \& Chaubey 2014).

Soil development at $\mathrm{AB}$ was slow compared to those at S27, C27 and MP. Plantations have been known to markedly improve the physical properties of soil, vegetation cover and natural regeneration in post mining sites (Zhao et al. 2013; Lei et al. 2015). The variations in soil bulk density, specific gravity, porosity, water holding capacity and soil aggregation in a reclaimed mine are mainly caused by variations in organic matter. As such, soil physical properties are largely related to the organic matter content (Charman \& Roper 2000; Zhao et al. 2013). 
Table 1 Soil physical properties on abandoned mining in the Phangnga Forestry Research Station and the reference sites

\begin{tabular}{|c|c|c|c|c|c|c|c|}
\hline \multirow{2}{*}{$\begin{array}{l}\text { Depth } \\
\text { (cm) }\end{array}$} & \multirow{2}{*}{ Site } & \multicolumn{3}{|c|}{ Soil particle $(\%)$} & \multirow{2}{*}{ Soil texture } & \multirow{2}{*}{$\begin{array}{c}\text { Bulk density } \\
\left(\mathrm{g} / \mathrm{m}^{3}\right)\end{array}$} & \multirow{2}{*}{$\begin{array}{c}\text { Porosity } \\
(\%)\end{array}$} \\
\hline & & Sand & Silt & Clay & & & \\
\hline \multirow[t]{6}{*}{$0-10$} & $\mathrm{AB}$ & $91.23^{a}$ & $3.99 \mathrm{c}$ & $4.77^{c}$ & Sandy & $1.31^{\mathrm{a}}$ & 56.99 \\
\hline & S27 & $89.33^{a}$ & $2.24^{c}$ & $8.42^{b c}$ & Loamy sand & $1.04^{\mathrm{ab}}$ & 59.67 \\
\hline & $\mathrm{C} 27$ & $17.70^{c}$ & $33.31^{\mathrm{a}}$ & $48.99^{a}$ & Clay & $0.94^{\mathrm{b}}$ & 59.43 \\
\hline & MP & $20.15^{c}$ & $33.47^{a}$ & $46.38^{a}$ & Clay & $0.90^{\mathrm{b}}$ & 60.40 \\
\hline & $\mathrm{SF}$ & $31.45^{\mathrm{c}}$ & $25.35^{\mathrm{ab}}$ & $43.20^{\mathrm{a}}$ & Clay & $0.96^{\mathrm{ab}}$ & 60.38 \\
\hline & $\mathrm{PF}$ & $67.73^{\mathrm{b}}$ & $8.71^{\mathrm{bc}}$ & $23.56^{\mathrm{b}}$ & Sandy clay loam & $0.92^{\mathrm{b}}$ & 65.93 \\
\hline \multicolumn{2}{|c|}{ F-value } & $110.16^{*}$ & $16.72^{*}$ & $29.38^{*}$ & & $4.08^{*}$ & $1.24^{\mathrm{ns}}$ \\
\hline \multirow[t]{6}{*}{$10-20$} & $\mathrm{AB}$ & $91.14^{\mathrm{a}}$ & $3.33^{c}$ & $5.56^{\mathrm{b}}$ & Sandy & $1.78^{a}$ & $32.86^{\mathrm{b}}$ \\
\hline & S27 & $87.97 \mathrm{ab}$ & $2.77^{c}$ & $7.76^{\mathrm{b}}$ & Loamy sand & $1.48^{\mathrm{b}}$ & $44.92^{\mathrm{a}}$ \\
\hline & C27 & $22.56^{c}$ & $26.93^{b}$ & $50.51^{\mathrm{a}}$ & Clay & $1.21^{\mathrm{c}}$ & $53.46^{\mathrm{a}}$ \\
\hline & MP & $9.03^{c}$ & $38.95^{\mathrm{a}}$ & $52.01^{\mathrm{a}}$ & Clay & $1.11^{\mathrm{c}}$ & $49.08^{a}$ \\
\hline & $\mathrm{SF}$ & $18.09^{c}$ & $21.26^{\mathrm{b}}$ & $60.65^{\mathrm{a}}$ & Clay & $1.09^{c}$ & $55.69^{\mathrm{a}}$ \\
\hline & $\mathrm{PF}$ & $67.11^{\mathrm{b}}$ & $7.24^{c}$ & $25.65^{\mathrm{b}}$ & Sandy clay loam & $1.22^{\mathrm{c}}$ & $54.55^{\mathrm{a}}$ \\
\hline \multicolumn{2}{|c|}{ F-value } & $64.30^{*}$ & $64.89^{*}$ & $30.72^{*}$ & & $45.57^{*}$ & $13.91^{*}$ \\
\hline \multirow[t]{6}{*}{$20-30$} & $\mathrm{AB}$ & $90.06^{a}$ & $3.37^{b}$ & $6.56^{c}$ & Sandy & $1.71^{\mathrm{a}}$ & $30.28^{c}$ \\
\hline & S27 & $84.33^{\mathrm{a}}$ & $6.93^{b}$ & $10.07^{b c}$ & Loamy sand & $1.69^{a}$ & $35.62^{b c}$ \\
\hline & $\mathrm{C} 27$ & $28.37 \mathrm{bc}$ & $27.98^{\mathrm{a}}$ & $43.65^{\mathrm{ab}}$ & Clay & $1.30^{\mathrm{b}}$ & $46.12^{\mathrm{ab}}$ \\
\hline & MP & $17.70^{c}$ & $26.05^{\mathrm{a}}$ & $56.25^{\mathrm{a}}$ & Clay & $1.17^{\mathrm{b}}$ & $49.87^{a}$ \\
\hline & $\mathrm{SF}$ & $26.37 \mathrm{bc}$ & $19.19^{\mathrm{ab}}$ & $54.44^{a}$ & Clay & $1.21^{\mathrm{b}}$ & $46.97^{\mathrm{ab}}$ \\
\hline & PF & $63.85^{\mathrm{ab}}$ & $5.38^{\mathrm{b}}$ & $30.77 \mathrm{ab}$ & Sandy clay loam & $1.33^{\mathrm{b}}$ & $43.78^{\mathrm{ab}}$ \\
\hline \multicolumn{2}{|c|}{ F-value } & $13.13^{*}$ & $8.37^{*}$ & $10.29^{*}$ & & $22.56^{*}$ & $7.97^{*}$ \\
\hline \multirow[t]{6}{*}{$30-50$} & $\mathrm{AB}$ & $90.57^{a}$ & $3.21^{\mathrm{c}}$ & $6.22^{\mathrm{d}}$ & Sandy & $1.58^{\mathrm{a}}$ & $38.14^{\mathrm{b}}$ \\
\hline & S27 & $81.71^{\mathrm{ab}}$ & $4.86^{c}$ & $13.43^{\mathrm{cd}}$ & Loamy sand & $1.55^{\mathrm{ab}}$ & $41.45^{\mathrm{ab}}$ \\
\hline & $\mathrm{C} 27$ & $31.23^{\mathrm{cd}}$ & $26.12^{\mathrm{ab}}$ & $42.65^{\mathrm{ab}}$ & Clay & $1.12^{\mathrm{c}}$ & $53.63^{\mathrm{a}}$ \\
\hline & MP & $8.44^{\mathrm{d}}$ & $33.52^{\mathrm{a}}$ & $58.04^{\mathrm{ab}}$ & Clay & $1.05^{\mathrm{c}}$ & $52.14^{\mathrm{a}}$ \\
\hline & SF & $18.42^{\mathrm{d}}$ & $18.93^{\mathrm{b}}$ & $62.65^{\mathrm{a}}$ & Clay & $1.12^{\mathrm{c}}$ & $52.78^{a}$ \\
\hline & $\mathrm{PF}$ & $55.89^{\mathrm{bc}}$ & $9.12^{\mathrm{c}}$ & $34.98^{\mathrm{bc}}$ & Sandy clay loam & $1.30^{\mathrm{bc}}$ & $42.92^{\mathrm{ab}}$ \\
\hline \multicolumn{2}{|c|}{ F-value } & $31.88^{*}$ & $53.83^{*}$ & $19.99^{*}$ & & $17.34^{*}$ & $6.51^{*}$ \\
\hline
\end{tabular}

Note: ${ }^{*}=$ Different superscripts along the same column indicate significant differences at $\mathrm{p}<0.05$.

Comparison between the rehabilitated sites, S27, C27 and MP, and the reference sites, SF and $\mathrm{PF}$, indicate that the bulk density and porosity were not significantly different, especially at the top soil. Invariably, the forest plantation had a significant role in improving the bulk density. However, the restoration of soil texture at these sites to that of the levels of PF, and in particular the sandy area with a poor soil quality, can take a long time (Oktavia et al. 2015). While soil bulk density and porosity in SF were similar to that in $\mathrm{PF}$, degradation of the soil structure due to shifting cultivation in SF may be lesser in extent compared to that in the mined out area.

\section{Soil Chemical Properties}

Soil $\mathrm{pH}$ was extremely acidic in S27, C27, MP and SF, while in $\mathrm{PF}$ it was strongly to moderately acidic. However, soil $\mathrm{pH}$ in $\mathrm{AB}$ was moderately to slightly acidic. These results indicate that the $A$. mangium plantation had a significant influence in reducing soil $\mathrm{pH}$, an observation similar to that of Yamashita et al. (2008). Amounts of exchangeable $\mathrm{K}$ and $\mathrm{Mg}$ were significantly different among the sites at depths of $0-10,10-20,20-30$, and $30-50 \mathrm{~cm}$. Mining rehabilitation with A. mangium plantation resulted in increased $\mathrm{K}$ and $\mathrm{Mg}$ levels which were higher than those in AB. Nevertheless, $\mathrm{K}$ and $\mathrm{Ca}$ of S27, C27 and $\mathrm{MP}$ were lower than those in SF and PF. The levels of $\mathrm{K}, \mathrm{Ca}$ and $\mathrm{Mg}$ were relatively high in the topsoil. Similarly, the available P, total $\mathrm{N}$ and OM were the highest at a depth of $0-10 \mathrm{~cm}$, but was decreasing with the increasing soil depth.

The topsoil was rich and higher in soil nutrient content, total $\mathrm{N}, \mathrm{OM}$, the available $\mathrm{P}$, $\mathrm{K}, \mathrm{Ca}$ and $\mathrm{Mg}$ in S27, C27 and MP than those in $\mathrm{AB}$. In mining restoration, the soil nutrients 
Table 2 Soil chemical properties in abandoned mining in the Phangnga Forestry Research Station and the reference sites

\begin{tabular}{|c|c|c|c|c|c|c|c|c|}
\hline \multirow{2}{*}{$\begin{array}{l}\text { Depth } \\
(\mathrm{cm})\end{array}$} & \multirow{2}{*}{ Site } & \multirow{2}{*}{$\mathrm{pH}$} & \multicolumn{3}{|c|}{ Exchangeable $(\mathrm{mg} / \mathrm{kg})$} & \multirow{2}{*}{$\begin{array}{c}\text { Available P } \\
(\mathrm{mg} / \mathrm{kg})\end{array}$} & \multirow{2}{*}{$\begin{array}{c}\text { Total N } \\
(\%)\end{array}$} & \multirow{2}{*}{$\begin{array}{l}\mathrm{OM} \\
(\%)\end{array}$} \\
\hline & & & $\mathrm{K}$ & $\mathrm{Ca}$ & $\mathrm{Mg}$ & & & \\
\hline \multirow[t]{6}{*}{$0-10$} & $\mathrm{AB}$ & $5.9^{a}$ & $6.33^{\mathrm{d}}$ & 10.69 & $2.92^{c}$ & $5.90^{\mathrm{b}}$ & $0.01^{\mathrm{c}}$ & $0.67^{c}$ \\
\hline & $\mathrm{S} 27$ & $4.5^{b c}$ & $14.38^{\mathrm{cd}}$ & 18.45 & $10.26^{\mathrm{bc}}$ & $12.91^{\mathrm{b}}$ & $0.11^{\mathrm{b}}$ & $1.62^{\mathrm{bc}}$ \\
\hline & C27 & $4.4^{c}$ & $35.37 \mathrm{bc}$ & 23.98 & $33.56^{\mathrm{ab}}$ & $15.16^{\mathrm{b}}$ & $0.13^{\mathrm{ab}}$ & $2.14^{\mathrm{b}}$ \\
\hline & $\mathrm{MP}$ & $4.7^{b}$ & $38.93^{b}$ & 27.46 & $35.34^{\mathrm{a}}$ & $9.42^{\mathrm{b}}$ & $0.10^{\mathrm{b}}$ & $1.66^{b c}$ \\
\hline & $\mathrm{SF}$ & $4.2^{c}$ & $82.27^{a}$ & 29.06 & $24.27 \mathrm{abc}$ & $33.32^{\mathrm{a}}$ & $0.17^{\mathrm{a}}$ & $2.42^{\mathrm{ab}}$ \\
\hline & PF & $4.8^{\mathrm{b}}$ & $40.25^{\mathrm{b}}$ & 29.56 & $26.72^{\mathrm{abc}}$ & $50.78^{a}$ & $0.17^{\mathrm{a}}$ & $3.55^{\mathrm{a}}$ \\
\hline \multicolumn{2}{|c|}{ F-value } & $68.53^{*}$ & $28.60^{*}$ & $1.40^{\mathrm{ns}}$ & $6.57^{*}$ & $70.22^{*}$ & $26.06^{*}$ & $15.38^{*}$ \\
\hline \multirow[t]{6}{*}{$10-20$} & $\mathrm{AB}$ & $6.0^{\mathrm{a}}$ & $7.46^{\mathrm{b}}$ & 11.17 & $3.21^{\mathrm{c}}$ & $4.34^{c}$ & $0.01^{\mathrm{c}}$ & $0.33^{b}$ \\
\hline & $\mathrm{S} 27$ & $4.7^{\mathrm{bc}}$ & $9.76^{\mathrm{b}}$ & 9.27 & $3.77 \mathrm{bc}$ & $7.10^{\mathrm{bc}}$ & $0.04^{\mathrm{c}}$ & $0.91^{\mathrm{b}}$ \\
\hline & C27 & $4.6^{\mathrm{bc}}$ & $20.42^{\mathrm{b}}$ & 11.81 & $15.91^{\mathrm{abc}}$ & $7.67 \mathrm{bc}$ & $0.04^{c}$ & $0.57^{b}$ \\
\hline & $\mathrm{MP}$ & $4.8^{\mathrm{bc}}$ & $24.07^{\mathrm{b}}$ & 11.13 & $26.93^{a}$ & $5.32^{\mathrm{bc}}$ & $0.04^{\mathrm{c}}$ & $0.86^{\mathrm{b}}$ \\
\hline & $\mathrm{SF}$ & $4.4^{c}$ & $64.34^{\mathrm{a}}$ & 12.83 & $17.38^{\mathrm{a}}$ & $6.25^{b c}$ & $0.11^{\mathrm{b}}$ & $1.49^{\mathrm{ab}}$ \\
\hline & PF & $4.9^{\mathrm{b}}$ & $29.57^{\mathrm{b}}$ & 12.00 & $16.34^{\mathrm{ab}}$ & $14.52^{\mathrm{a}}$ & $0.15^{\mathrm{a}}$ & $2.53^{\mathrm{a}}$ \\
\hline \multicolumn{2}{|c|}{ F-value } & $35.03^{*}$ & $19.40^{*}$ & $1.45^{\mathrm{ns}}$ & $11.08^{*}$ & $15.31^{*}$ & $73.57^{*}$ & $6.65^{*}$ \\
\hline \multirow[t]{6}{*}{$20-30$} & $\mathrm{AB}$ & $5.8^{\mathrm{a}}$ & $5.18^{c}$ & 10.26 & $3.13^{\mathrm{b}}$ & $3.22^{\mathrm{b}}$ & $0.01^{\mathrm{c}}$ & $0.25^{\mathrm{b}}$ \\
\hline & $\mathrm{S} 27$ & $4.9^{\mathrm{b}}$ & $8.17^{c}$ & 9.58 & $4.74^{\mathrm{b}}$ & $7.32^{\mathrm{ab}}$ & $0.02^{c}$ & $0.71^{b}$ \\
\hline & $\mathrm{C} 27$ & $4.6^{\mathrm{b}}$ & $9.97 \mathrm{bc}$ & 9.76 & $18.23^{\mathrm{b}}$ & $7.36^{\mathrm{ab}}$ & $0.03^{\mathrm{bc}}$ & $0.36^{\mathrm{b}}$ \\
\hline & $\mathrm{MP}$ & $4.9^{\mathrm{b}}$ & $19.07 \mathrm{abc}$ & 9.59 & $35.42^{\mathrm{a}}$ & $4.86^{\mathrm{ab}}$ & $0.04^{\mathrm{bc}}$ & $0.47^{b}$ \\
\hline & SF & $4.6^{\mathrm{b}}$ & $33.14^{\mathrm{a}}$ & 14.21 & $9.87^{\mathrm{ab}}$ & $5.65^{\mathrm{ab}}$ & $0.07^{\mathrm{b}}$ & $1.21^{\mathrm{ab}}$ \\
\hline & $\mathrm{PF}$ & $5.6^{\mathrm{a}}$ & $24.08^{\mathrm{ab}}$ & 10.59 & $16.45^{\mathrm{b}}$ & $9.15^{\mathrm{a}}$ & $0.13^{\mathrm{a}}$ & $2.29^{\mathrm{a}}$ \\
\hline \multicolumn{2}{|c|}{ F-value } & $31.28^{*}$ & $11.44^{*}$ & $1.01^{\mathrm{ns}}$ & $11.94^{*}$ & $4.81^{*}$ & $31.29^{*}$ & $6.84^{*}$ \\
\hline \multirow[t]{6}{*}{$30-50$} & $\mathrm{AB}$ & $6.1^{\mathrm{a}}$ & $5.01^{\mathrm{c}}$ & 9.12 & $2.85^{c}$ & 3.05 & $0.01^{\mathrm{b}}$ & $0.19^{\mathrm{b}}$ \\
\hline & $\mathrm{S} 27$ & $5.1^{\mathrm{b}}$ & $6.19^{c}$ & 7.86 & $2.49^{c}$ & 5.54 & $0.01^{\mathrm{b}}$ & $0.48^{b}$ \\
\hline & C27 & $4.8^{\mathrm{bc}}$ & $10.75^{b c}$ & 12.41 & $18.53^{\mathrm{ab}}$ & 7.12 & $0.02^{\mathrm{ab}}$ & $0.54^{\mathrm{b}}$ \\
\hline & $\mathrm{MP}$ & $4.9^{\mathrm{bc}}$ & $18.68^{\mathrm{ab}}$ & 12.50 & $31.51^{\mathrm{a}}$ & 2.62 & $0.02^{\mathrm{ab}}$ & $0.41^{\mathrm{b}}$ \\
\hline & $\mathrm{SF}$ & $4.6^{c}$ & $20.12^{\mathrm{ab}}$ & 9.94 & $5.94^{\mathrm{bc}}$ & 3.59 & $0.04^{\mathrm{a}}$ & $0.87^{b}$ \\
\hline & PF & $5.7^{\mathrm{a}}$ & $20.76^{a}$ & 5.03 & $17.23^{\mathrm{b}}$ & 7.08 & $0.04^{\mathrm{a}}$ & $2.16^{\mathrm{a}}$ \\
\hline \multicolumn{2}{|c|}{ F-value } & $43.13^{*}$ & $12.70^{*}$ & $3.21^{\mathrm{ns}}$ & $15.41^{*}$ & $5.95^{\text {ns }}$ & $7.37^{*}$ & $8.95^{*}$ \\
\hline
\end{tabular}

Notes: ${ }^{*}=$ significant difference; $\mathrm{ns}=$ non-significant difference; and $\mathrm{a}-\mathrm{c}=$ different superscripts along a column indicate significant differences at $\mathrm{p}<0.05$.

and organic matter contents usually increased with the age of the stand (Zhao et al. 2013; Bohre \& Chaubey 2014). Soil nutrients rapidly increased in plantations using a nitrogen fixing tree while natural succession increased gradually (Oktavia et al. 2015). However, soil nutrients such as exchangeable $\mathrm{K}$, available $\mathrm{P}$, total $\mathrm{N}$ and OM levels at S27, C27 and MP were lower than those in both SF and PF at a depth of $0-10 \mathrm{~cm}$. Overall, the soil properties in SF particularly, available $\mathrm{P}$, total $\mathrm{N}$ and $\mathrm{OM}$ contents were improved faster than those in S27, C27 and MP. Although A. mangium was dominant in S27, C27 and MP, the level of total $\mathrm{N}$ was relatively low, particularly in the sandy area. These results indicate that mining activities highly impacted the soil properties and the restoration may take a longer time.

\section{Tree Composition and Ecological Characteristics}

There were 21, 34, 40, 81 and 94 tree species, 19, 29, 31, 62 and 68 genera, and 14, 26, 25, 33 and 38 families in the S27, C27, MP, SF and PF, respectively. The basal area, density and species diversity index in PF (3.91) was the highest, in contrast with those in S27 (1.43), which had the lowest density and species diversity index (Table 3). Soil characteristics showed a significant influence on the density, species diversity index, and natural regeneration (Lei et al. 2015), especially in the S27. Soil texture in the area being sandy, has a low water holding capacity, and thus, has resulted in insufficient water supply during the dry season, a phenomenon causing high seedling mortality in the tropical rain forests ( $\mathrm{Li}$ et al. 2011). Soil properties play important roles on revegetation 
Table 3 Ecological characteristics of the rehabilitated sites, S27, C27 and MP in the Phangnga Forestry Research Station, Thailand and the reference sites, SF and PF

\begin{tabular}{cccccc}
\hline \multirow{2}{*}{ Ecological characteristics } & \multicolumn{5}{c}{ Sites } \\
\cline { 2 - 6 } & S27 & C27 & MP & SF & PF \\
\hline Number of species & 21.00 & 34.00 & 40.00 & 81.00 & 94.00 \\
Basal area (m²/ha) & 35.49 & 20.91 & 23.09 & 22.20 & 41.27 \\
Density (stems/ha) & $1,010.42$ & $1,229.17$ & $1,393.75$ & $1,200.00$ & $1,497.92$ \\
Shannon - Wiener index $\left(H^{\prime}\right)$ & 1.43 & 2.51 & 2.77 & 3.86 & 3.91 \\
Evenness of species & 0.46 & 0.71 & 0.74 & 0.88 & 0.86 \\
\hline
\end{tabular}

of native trees and forest community (Zhao et al. 2013; Lei et al. 2015).

The number of species, tree diversity and density was significantly lower in S27 and C27, than those in MP, which consisted of $A$. mangium, E. camaldulensis and D. alatus. A mixed plantation of many tree species can facilitate a successful seedling establishment in the understory and native trees were also found more abundantly than in pure plantations, resulting in a high tree diversity (Wang et al. 2019). However, the rehabilitated sites in S27, C27 and MP had a low tree diversity compared to SF. The number of native tree species found in S27, C27 and MP were relatively less than that in $\mathrm{SF}$, resulting in a low recovery of original tree species, forest structure, and forest function. In addition, species richness and evenness in $\mathrm{SF}$ was larger than those in S27, C27 and MP, resulting in high tree diversity. Tree diversity is related with species richness and evenness (Strong 2016). According to the ShannonWiener index of the old teak (Tectona grandis) plantation was higher when the evenness value of the plot was high (Koonkhunthod et al. 2007). In addition, the Shannon-Wiener index in S27 (1.43), C27 (2.51) and MP (2.77) was lower than that in a 34-year-old A.mangium plantation (3.22) (Marod et al. 2013). A. mangium plantation can be highly effective to introduce native trees species (Van et al. 2005). In this study, the native species were mostly shade intolerant trees. Therefore, accelerating the natural succession by enrichment planting with poorly dispersed shade tolerant trees, such as Swintonia floribunda, Dipterocarpus kerrii, Canarium patentinervium, Xanthophyllum virens, Mesua ferrea, Hopea griffithii and Gluta elegans, may be considered in S27, C27 and MP for improving the forest structure and increasing the tree diversity.

The high tree diversity and number of trees in $\mathrm{SF}$ could be due to various factors such as proximity to the forest fragment, rich soil nutrient content and organic matter. The vegetation composition and richness decrease with the increasing distance from the primary forest (Van et al. 2005; Ruiz-Jaen \& Aide 2005). Therefore, the distance from a natural forest and the surrounding mining area with oil palm and rubber plantations had largely obstructed on the process of natural forest succession in the S27, C27 and MP.

This study, we showed top seven IVI in S27, C27, MP, SF and PF because they play ecological importance in ecosystem with high relative frequency, density and basal area. The dominant native trees in S27, C27 and MP included Vitex pinnata, Aporosa planchoniana, Carallia brachiata, Melicope lunu-ankenda and Bridelia tomentosa (Table 4). Most native species were identified as pioneers because of their various life forms such as very fast growth, frequent year-round flowering, production of a large number of small seeds, lighting demand for germination, and low wood density are often shade intolerant trees (Goosem \& Tucker 2013; Elliott et al. 2013). Similarly, the dominant trees in SF were also classified as pioneers, such as Eurya acuminata, Microcos paniculata, and Vitex pinnata. These trees are mostly found in disturbed areas (Sinbumroong 2009) and old plantation (Koonkhunthod et al. 2007). Pioneer trees are tolerant to adverse environmental conditions; therefore, these species can be considered for restoring other degraded areas.

Twenty seven trees recorded were in both SF and PF, among which are Barringtonia macrostachya, Diospyros wallichii, Canarium patentinervium, and Garcinia cowa. However, these were only few small trees. Revegetation in SF was faster than in S27, C27 and MP, resulting in a complex forest structure and high tree diversity. The similarity index between $\mathrm{PF}$ and SF was $31.03 \%$, PF with MP was $8.00 \%$, PF 
with C27 was $6.98 \%$, and PF with S27 was $5.83 \%$ (Table 5). The similarity index between the rehabilitated sites in the mining area and $\mathrm{PF}$ was low suggesting that SF may be in a mid- successional status and the rehabilitated sites at S27, C27 and MP were in early successional status, as indicated by their similarity index (Habich 2001).

Table 4 Importance Value Index (IVI), Relative Density (RD), Relative Frequency (RF) and Relative Basal Areas (RDo) of the top seven trees in S27, C27, MP, SF and PF

\begin{tabular}{|c|c|c|c|c|c|c|}
\hline Site & Tree species & Family & $\mathrm{RD}$ & RF & RDo & IVI \\
\hline \multirow[t]{8}{*}{ S27 } & Acacia mangium & Fabaceae & 63.85 & 35.60 & 95.15 & 194.60 \\
\hline & Aporosa planchoniana & Phyllanthaceae & 16.45 & 15.15 & 1.21 & 32.81 \\
\hline & Carallia brachiata & Rhizophoraceae & 4.33 & 9.85 & 0.54 & 14.72 \\
\hline & Bridelia tomentosa & Phyllanthaceae & 3.25 & 7.58 & 0.38 & 11.21 \\
\hline & Vitex pinnata & Lamiaceae & 1.95 & 6.06 & 0.74 & 8.75 \\
\hline & Litsea grandis & Lauraceae & 1.52 & 4.55 & 0.22 & 6.29 \\
\hline & Morinda coreia & Rubiaceae & 1.73 & 3.03 & 0.38 & 5.14 \\
\hline & Other species & & 6.92 & 18.18 & 1.38 & 26.48 \\
\hline \multirow[t]{8}{*}{$\mathrm{C} 27$} & Melicope lunu-ankenda & Rutaceae & 18.19 & 15.11 & 26.59 & 59.89 \\
\hline & Acacia mangium & Fabaceae & 38.83 & 6.22 & 6.55 & 51.60 \\
\hline & Aporosa planchoniana & Phyllanthaceae & 5.65 & 7.11 & 17.73 & 30.49 \\
\hline & Carallia brachiata & Rhizophoraceae & 8.74 & 9.33 & 11.56 & 29.63 \\
\hline & Vitex pinnata & Lamiaceae & 5.61 & 8.89 & 6.17 & 20.66 \\
\hline & Ilex cymosa & Aquifoliaceae & 1.92 & 8.00 & 6.36 & 16.28 \\
\hline & Fagraea fragrans & Gentianaceae & 2.93 & 11.11 & 1.93 & 15.97 \\
\hline & Other species & & 23.11 & 34.23 & 18.13 & 75.47 \\
\hline \multirow[t]{8}{*}{ MP } & Eucalyptus camaldulensis & Myrtaceae & 10.23 & 9.45 & 47.12 & 66.80 \\
\hline & Acacia mangium & Fabaceae & 15.27 & 8.54 & 20.78 & 44.59 \\
\hline & Fagraea fragrans & Gentianaceae & 15.44 & 10.06 & 5.50 & 31.00 \\
\hline & Ilex cymosa & Aquifoliaceae & 15.10 & 9.45 & 3.22 & 27.77 \\
\hline & Dipterocarpus alatus & Dipterocarpaceae & 6.21 & 6.71 & 1.73 & 14.65 \\
\hline & Vitex pinnata & Lamiaceae & 2.18 & 3.96 & 8.56 & 14.70 \\
\hline & Carallia brachiata & Rhizophoraceae & 4.19 & 6.10 & 1.47 & 11.76 \\
\hline & Other species & & 31.38 & 45.73 & 11.62 & 88.73 \\
\hline \multirow[t]{8}{*}{$\mathrm{SF}$} & Eurya acuminata & Pentaphylacaceae & 12.24 & 7.07 & 13.79 & 33.10 \\
\hline & Gmelina arborea & Lamiaceae & 5.60 & 4.08 & 20.90 & 30.58 \\
\hline & Microcos paniculata & Malvaceae & 5.39 & 4.62 & 10.21 & 20.22 \\
\hline & Barringtonia macrostachya & Lecythidaceae & 5.81 & 6.25 & 1.63 & 13.69 \\
\hline & Vitex pinnata & Lamiaceae & 3.11 & 2.99 & 4.86 & 10.96 \\
\hline & Diospyros wallichii & Ebenaceae & 4.77 & 4.08 & 1.94 & 10.79 \\
\hline & Garcinia cowa & Clusiaceae & 2.28 & 2.72 & 4.27 & 9.27 \\
\hline & Other species & & 60.80 & 68.19 & 42.40 & 171.39 \\
\hline \multirow[t]{8}{*}{ PF } & Swintonia floribunda & Anacardiaceae & 5.93 & 4.56 & 19.72 & 30.21 \\
\hline & Dipterocarpus kerrii & Dipterocarpaceae & 4.17 & 4.36 & 13.64 & 22.17 \\
\hline & Canarium patentinervium & Burseraceae & 7.37 & 4.77 & 2.05 & 14.19 \\
\hline & Xanthophyllum virens & Polygalaceae & 4.17 & 4.56 & 5.26 & 13.99 \\
\hline & Mesua ferrea & Calophyllaceae & 2.04 & 2.70 & 8.17 & 12.91 \\
\hline & Hopea griffithii & Dipterocarpaceae & 4.97 & 4.77 & 2.11 & 11.85 \\
\hline & Gluta elegans & Anacardiaceae & 3.69 & 3.11 & 4.07 & 10.87 \\
\hline & Other species & & 67.66 & 71.17 & 44.98 & 183.81 \\
\hline
\end{tabular}

Table 5 Sørensen similarity index of tree species among S27, C27 and MP compared with SF and PF

\begin{tabular}{ccc}
\hline Site & SF & PF \\
\hline S27 & 17.48 & 5.83 \\
C27 & 22.61 & 6.98 \\
MP & 23.53 & 8.00 \\
SF & 100.00 & 31.03 \\
PF & 31.03 & 100.00 \\
\hline
\end{tabular}




\section{CONCLUSION}

The $A$. mangium plantation in the abandoned tin mining area played a key role in the soil improvement particularly, the top soil. The bulk density and porosity of soil under the plantation remarkably improved. The level of soil nutrients, particularly, organic matter and total $\mathrm{N}$, increased as a result of the presence of A. mangium trees. However, these quantities were lower than those measured in the secondary and primary forests. The tree diversity and number of species were low in the sandy soil type in S27 (1.43), clay soil type in C27 (2.51), and mixed plantation in MP (2.77). Moreover, the tree similarity indices in S27, C27, and MP, as well as in primary forest PF were relatively low $(5.83-8.00)$. These results showed that plant development in S27, C27, and MP was slow and the dominant trees in the rehabilitated mining sites and the $\mathrm{SF}$ were mostly identified as belonging to the pioneer species group, suggesting that enrichment planting with poorly dispersed shade tolerant trees should be considered in improving tree diversity and forest structure and eventually, the ecosystem processes in these areas. Nonetheless, the complexity of the forest structure and tree community in the rehabilitated area was a result of the A. mangium plantation, particularly the mixed plantation (MP). These results indicate the potential of $A$. mangium trees in restoring previously mined areas. Meanwhile, pioneer trees such as Vitex pinnata, Carallia brachiata, Microcos paniculata, and Eurya acuminata can also be selected for restoring other degraded lands.

\section{ACKNOWLEDGEMENTS}

The authors are grateful for the financial support provided by the Kasetsart University Research and Development Institute (KURDI), Thailand and for the field assistance of the staff at the Phangnga Forestry Research Station.

\section{REFERENCES}

Barrantes G, Sandoval L. 2009. Conceptual and statistical problems associated with the use of diversity indices in ecology. Rev Biol Trop 57:451-61.
Bohre P, Chaubey OP. 2014. Restoration of degraded lands through plantation forests. Global J Sci Frontier Res 14(1):19-27.

Celentano D, Zahawi RA, Finegan B, Ostertag R, Cole RJ, Holl KD. 2011. Litterfall dynamics under different tropical forest restoration strategies in Costa Rica. Biotropica 43:278-87.

Charman PEV, Roper MM. 2000. Soil organic matter. In: Charman PEV, Murphy BW, editors. Soil: Their Properties and Management. Melbourne (AU): Land and Water Conservation, New South Wale and Oxford University Press. p. 260-70.

Elliott S, Blakesley D, Hardwick K. 2013. Restoring tropical forest: A practical guide. Kew (UK): Royal Botanic Gardens Kew.

Estefan G, Sommer R, Ryan J. 2013. Methods of soil, plant and water analysis: A manual for the West Asia and North Africa Region. $3^{\text {rd }}$ ed. Beirut (LB): ICARDA.

Goosem S, Tucker NIJ. 2013. Repairing the rainforest. Cairns (AU): Wet Tropics Management Authority and Biotropica Australia Pty. Ltd.

Habich EF. 2001. Ecological site inventory, Technical Reference 1734-7. Denver (US): Bureau of Land Management.

Jackson ML. 1965. Soil chemical analysis-advance course. Wisconsin (US): Department of Soils, University of Wisconsin.

Koonkhunthod N, Sakurai K, Tanaka S. 2007. Composition and diversity of woody regeneration in a 37 -year-old teak (Tectona grandis L.) plantation in northern Thailand. For Ecol Manage 247:246-54.

Lei H, Peng Z, Yigang H, Yang Z. 2015. Vegetation succession and soil infiltration characteristics under different aged refuse dumps at the Heidaigou. Glob Ecol Conserv 4:255-63.

Li P, Huang ZL, Xiang YC, Ren H. 2011. Survival, growth and biomass of Acacia auriculiformis and Schima superba seedlings in different forest restoration phases in Nanao island, South China. J Trop For Sci 23(2):177-86.

Macdonald SE, Landhausser SM, Skousen J, Franklin J, Frouz J, Hall S, ... Quideau S. 2015. Forest restoration following surface mining disturbance: Challenges and solutions. New Forests 46:703-32.

Marod D, Panichsuay K, Thinkamphaeng S, A-sanok L. 2013. Natural regeneration of native plant species after rehabilitation of disturbed dry evergreen forest in Sakaerat Environmental Research Station, Nakhonratchasima province. In: Thai Forest Ecology Research Network: Ecology Knowledge for Restoration. Proceedings: 2013 Jan 26-24. Bangkok (TH): Thai Forest Ecological Research Network. p. 168-79. 
Martínez-Ruiz C, Fernández-Santos B. 2005. Natural revegetation on topsoiled mining-spoils according to the exposure. Acta Oecol 28:231-8.

Martpalakorn M. 1990. Tree species trials on mined spoils at Amphoe Takuapa, Changwat Phangnga [Dissertation]. Retrieved from Kasetsart University.

Nambiar EKS, Harwood CE. 2014. Productivity of acacia and eucalypt plantations in Southeast Asia 1. Biophysical determinants of production: Opportunities and challenges. Int Forest Rev 16:225-48.

Oktavia D, Setiadi Y, Hilwan I. 2015. The comparison of soil properties in heath forest and post-tin mined land: Basic for ecosystem restoration. Procedia Environ Sci 28:124-31.

Parrotta JA. 1999. Productivity, nutrient cycling, and succession in single and mixed-species plantations of Casuarina equisetifolia, Eucalyptus robusta, and Leucaena leucocephala in Puerto Rico. For Ecol Manage 124:45-77.

Pielou EC. 1966. The measurement of diversity in different types of biological collections. J Theoret Biol 13:131-44.

Ruiz-Jaen M, Aide TM. 2005. Vegetation structure, species diversity, and ecosystem process as measures of restoration success. For Ecol Manage 218:159-73.

Shannon CE, Weaver W. 1949. The mathematical theory of communication. Urbana (US): University of Illinois Press.

Sinbumroong A. 2009. Structure and floristic composition of wet seasonal evergreen forest at Khao Ban Thad Wildlife Sanctuary, Trang province [Dissertation]. Retrieved from Kasetsart University.

Sørensen T. 1948. A method of establishing groups of equal amplitude in plant sociology based on similarity of species content, and its application to analyses of the vegetation on Danish commons. Biol Skr 5:1-34.
Strong WL. 2016. Biased richness and evenness relationships within Shannon-Wiener index values. Ecol Indic 67:703-13.

Tripathi N, Singh RS, Hills CD. 2016. Reclamation of mine-impacted land for ecosystem recovery. New Jersey (US): John Wiley \& Sons.

Van DT, Lee DK, Van TH. 2005. Rehabilitation of native tree species in the forest plantations and denuded hills of Namlau commune in Sonla province, Vietnam. For Sci Technol 1:51-8.

Wang F, Li Z, Xia H, Zou B, Li N, Liu J, Zhu W. 2010. Effects of nitrogen-fixing and non-nitrogen-fixing tree species on soil properties and nitrogen transformation during forest restoration in southern China. Soil Sci Plant Nutr 56:297-306.

Wang X, Hua F, Wang L, Wilcove DS, Yu DW. 2019. The biodiversity benefit of native forests and mixedspecies plantations over monoculture plantations. Divers Distrib 25:1721-35.

Wongprom J, Maelim S, Teejuntuk S, Sommeechai M. 2013. Effects of thinning on growth and yield of Acacia mangium Willd. under naturally regenerated on abandoned mining area in Phang-Nga Forestry Research Station. Thai J For 32:142-51.

Yamashita N, Ohta S, Hardjono A. 2008. Soil changes induced by Acacia mangium plantation establishment: comparison with secondary forest and Imperata cylindrical grassland soils in south Sumatra, Indonesia. For Ecol Manage 254:362-70.

Zhao Z, Shahrour I, Bai Z, Fan W, Feng L, Li H. 2013. Soil development in opencast coal mine spoils reclaimed for 1-13 years in the West-Northern Loess Plateau of China. Eur J Soil Biol 55:40-6.

Zhang Y, Yang JY, Wu HL, Shi CQ, Zhang CL, Li DX, Feng MM. 2014. Dynamic changes in soil and vegetation during varying ecological recovery conditions of abandoned mines in Beijing. Ecol Eng 73:676-83. 